\title{
Pharmacognostical, Phytochemical and Total Phenolic Content of Artocarpus altilis (Parkinson) F osberg Leaves
}

\author{
Mukesh S. Sikarwar ${ }^{1 *}$, BoeyJia Hui ${ }^{2}$, Kumutha Subramaniam², Bavani Devi Valeisamy ${ }^{2}$, Ling KarYean ${ }^{2}$, Kaveti Balaji ${ }^{1}$ \\ ${ }^{1}$ Unit of Pharmaceutical Chemistry, Faculty of Pharmacy, AIMST University, Semeling, Kedah DarulAman, Malaysia. \\ ${ }^{2}$ Research Student, Unit of Pharmaceutical Chemistry, Faculty of Pharmacy, AIMST University, Semeling, Kedah DarulAman, Malaysia.
}

\section{ARTICLE INFO \\ Article history: \\ Received on: 24/02/2015 \\ Revised on: 26/04/2015 \\ Accepted on:20/05/2015 \\ Available online: 27/05/2015}

Key words:

Total phenolic content, Artocarpus altilis, Pharmacognostical, Phytochemical.

\begin{abstract}
Objective: This research was aimed to investigate the pharmacognostical, phytochemical and total phenolic content of Artocarpus altilis(Parkinson) Fosberg leaves.

Method: Macroscopy, microscopy, physicochemical, phytochemical analysis and thin layer chromatography of Artocarpus altilis leaves were carried out. Folin-Coicalteau method was used to determine the total phenolic content.

Results: Morphological study showed that the leaves were alternate or irregular, ovate and finger-like shaped with an average of $30.21 \mathrm{~cm}$ in length and $24.25 \mathrm{~cm}$ in width. Microscopy on leaves and powder showed the presence of anomocytic stomata, trichomes, xylem, starch grains, lignin, and calcium oxalate crystals. Phytochemical test showed the presence of mucilage, flavonoid, steroid, tannin and phenolic compound and anthraquinone glycosides. Physicochemical analysis showed $11.64 \%$ of loss on drying, $9 \%$ of total ash value; and water soluble extractive value of $21.32 \%$ as highest. Total phenolic content was found to be $26.22 \mathrm{mg}$ GAE/g. Conclusion: From this study, it can be concluded that the ethanolic extracts of Artocarpus altilis leaves possess modest amount of phenolic compounds in the leaves of this plant.
\end{abstract}

\section{INTRODUCTION}

Herbal medicine in the simplest form are medicines or drugs made up from herbs or plants and can be said to process several synonyms all of which refer to plants as the raw materials for medicine namely, phytomedicines, plant medicines, green medicines, traditional medicine, traditional remedies plant drugs and forest health products among others. The World Health Organization also defined herbal medicine as finished labeled medicinal products that active ingredient contain aerial or underground parts of plants or other plant materials or combinations thereof whether in crude juices, gums and fatty oils and other substances of this nature.

\footnotetext{
* Corresponding Author

* Senior Lecturer, Faculty of Pharmacy,AIMST University ,Semeling, 08100 Bedong, Kedah DarulAman, Malaysia

Email: mukeshsikarwar@gmail.com,Ph:0060164823916
}

Herbal medicine may contain standard excipients in addition to the active ingredients. Medicines containing plant material combined with chemically defined active substances including chemically defined isolated constituents of plants are not considered to be herbal medicine. Exceptionally, in some countries herbal medicine may also contain by tradition, natural organic or inorganic active ingredients which are not of plant origin.

In this modern setting, ingredients are sometimes marketed for uses that were never considered in the traditional healing systems from which they emerged. Use of ephedra for weight loss or athletic performance enhancement is one of the examples. Meanwhile in some countries, herbal medicines are subjected to rigorous manufacturing standards, which is not seen everywhere. In Germany, herbal products are sold as 'phytomedicines', in which they are subjected to the same criteria for efficacy, safety and quality as are other drug products. In USA, by contrast, most herbal products are marketed and regulated as 
dietary supplements, a product category that does not require preapproval on the basis of any of these criteria (Osmene et al., 2011; Glatz, 2014).

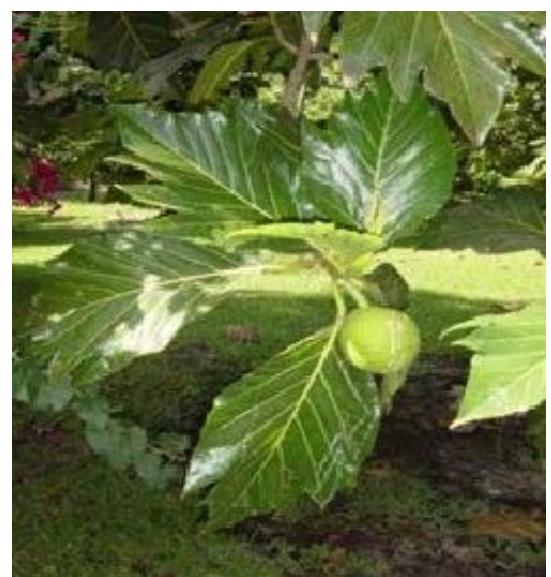

Fig. 1: Artocarpusaltilis (Parkinson) Fosberg leaves.

\section{ARTOCARPUS ALTILIS}

Artocarpus altilis (Moraceae) is a tropical fruit and the tree produces fruit twice in a year, from March to June and from July to September with some fruiting throughout the year (Motley, 2014). Breadfruit is also known to be a traditional starch rich crop. The genus Artocarpus (Moraceae) comprises of approximately 50 species and is widely distributed in tropical and subtropical regions (Jones et al., 2011).

The generic name of the species comes from the Greek words 'artos' (bread) and 'karpos' (fruit) and the fruits eaten are commonly called breadfruit. Synonyms of Artocarpus altilis are Artocarpus communis and Artocarpus incisus(Handa and Khanuja, 2008).Leaves are leathery with a dark-green colour on the dorsal side, which often appears to be glossy. The underside is dull with an elevated midrib and main veins. Leaves are spirally arranged or alternate and distichous, simple and are entire to pinnatifid or pinnate, coriaceous, glabrous to pubescent. At the end of the branches, the leaves are seen as clusters. The crown is conical in shape when the trees are young or grown under shaded condition and they become rounded and irregular when it turns older.

Basically Artocarpus species consists of phenolic compounds which include flavonoids, stilbenoids, arylbenzofurons and Jacalin, a lectin. Over 130 compounds are identified in various organs of the tree of Artocarpus altilis, more than 70 of which derived from the phenylpropanoid pathway (Amarasinghe et al., 2007). Leaves of Artocarpus altilis contain tannins, phenolics, glycosides, saponins, steroids, terpenoids and anthraquinones. Flavonoids are present in the petroleum ether and ethyl acetate leaf extracts, whereas tannins are detected only in the methanol leaf extract.It also contains phenolic compounds such as stilbenes, chalcones and flavones (Jagtap et al., 2010).

The extracts and metabolites of Artocarpus especially those from leaves, bark, stem and fruit possess several useful bioactive compounds and these compounds are used in the various biological activities including antibacterial, antitubercular, antiviral, antifungal, antiplatelet, antiarthritic, tyrosinase inhibitory and cytotoxicity (Somashekhar et al., 2013).The fruits are great source of carbohydrate and it has low fat. Since the fruit can be steamed, fried, baked, roasted and fried, they can be eaten at all stages of growth. Although breadfruits are rich in carbohydrates, but they are substituted partially for wheat flour in many products such as snacks, pastries and bread.

\section{TAXONOMICAL CLASSIFICATION}

(Somashekhar et al., 2013)

Kingdom: Plantae

Subkingdom: Mracheobionata

Division: Magnoliophyta

Class: Magnoliopsida

Subclass: Hamamelididae

Order: Rosales

Family: Moraceae

Genus: Artocarpus

Species: altilis

\section{USES}

\section{Pharmacological uses}

Many on-going researches are testing the pharmacological activities of Artocarpus altilis. Some of the researches that are being carried out based on these plants include anti-inflammatory, antioxidant, antifungal, immunomodulatory effect, antidiabetic effect, antibacterial effect, anti-cholinergic, nutritional assessment, cosmetic agent, ace inhibitors, anthelmintic effect, protease inhibitors, regulation of estrogens and Inhibition of melanin biosynthesis (Somashekhar et al., 2013).

\section{Traditional uses}

The senescence leaves is used in treatment of hypertension and diabetes in Caribbean. In Taiwan, leaves are used in treatment of liver disease and fever. Roasted leaf powder is used as remedy for enlarged spleen (Morton, 1987).

\section{INTERACTIONS (Anonyms, 2014)}

\section{5-Alpha reductase inhibitors}

Based on laboratory tests, heartwood extract of Artocarpus altilis may produce a potent 5-alpha reductase inhibitory activity, and care must be taken when using 5-alpha reductase inhibiting herbs and supplements, as the additive effects may cause some adverse reactions.

\section{Anticoagulants and antiplatelets}

Based on an in vitro study, root extracted from Artocarpus altilis can inhibit the formation of thromboxane (an inducer of platelet aggregation). Furthermore, breadfruit may theoretically potentiate the effects of other herbs and supplements that increase 


\section{Hematological agents}

According to the in vitro studies conducted on animals and humans, frutackin shows hemagglutination activity against erythrocytes and therefore they may have additive effects with antihemagglutinin herbs or supplements.

\section{MATERIAL AND METHOD}

\section{Collection}

Fresh leaves of Artocarpus altilis were collected in the month of March 2014 in and around campus of AIMST University, Kedah, Malaysia. The leaves were separated, washed thoroughly, shade dried for seven days and also dried by using hot air oven to quicken the drying process. Then, the leaves were homogenized to fine powder by using electronic blender and stored in air tight container.

\section{MACROSCOPY STUDY}

The plant was macroscopically examined for shape, size, surface, characteristic, texture, colour, odour, andtaste.

\section{MICROSCOPY STUDY}

\section{Microscopy on Transverse Section of Leaves}

The leaves were warmed with chloral hydrate solution to remove chlorophyll content. The transverse section of the leaves was cut from the apex and base of the leaves. The transverse section was mounted on clean glass slides and covered by the cover slips. Then the transverse section of the leave was stained with iodine, phloroglucinol and concentrated hydrochloric acid and $60 \%$ sulphuric acid in different glass slides. The slides were observed under light microscopes. The presence or absence of the characteristic features like epidermal cells, stomata, trichomes, xylem, phloem and others characteristics were observed and noted (Arya and Thakur, 2012).

\section{Powder Microscopy}

A small amount of powder was taken and boiled with chloral hydrate to remove chlorophyll. Then, it is stained with phloroglucinol solution for few minutes and followed by concentrated hydrochloric acid (1:1) on the slide. It was mixed well and allowed to stand for about 3 minutes. It was then covered with a cover slip and observed under light microscope. Similarly, the powder was also stained with weak iodine solution for the identification of starch grains. Powders were also treated with concentrated sulphuric acid $(60 \% \mathrm{v} / \mathrm{v})$ and dilute acetic acid for the identification of calcium oxalate crystals. The powder microscopic characteristics were observed and noted (Salahuddin et al., 2010).

\section{Physicochemical Evaluation of Crude Drugs}

All the crude drugs were subjected to physical and chemical evaluation for different parameters. Physical evaluation in the primary step is adopted in the identification and standardization of crude drugs. It helps in the determination of adulterants and validates the authenticity of crude drug. It is also the primary step adopted in the identification of chemical constituents and standardization of crude drug.

\section{Extractive Values (Jhanwar, 2013) \\ Determination of alcohol - soluble extractive}

$3 \mathrm{~g}$ of the air-dried coarsely powdered crude drug was macerated with $100 \mathrm{ml}$ ethanol of the specified strength in a closed flask for 24 hours; it was shaken for $6 \mathrm{~h}$ and was allowed to stand for the next $18 \mathrm{~h}$. Filtered rapidly taking precautions against loss of ethanol, $25 \mathrm{ml}$ of the filtrate was evaporated to dryness in tarred, flat bottomed, shallow dish and dried at $105^{\circ} \mathrm{C}$ to constant weight. The percentage of ethanol soluble extractive with reference to the air-dried drug was calculated.

Determination of water-soluble, chloroform-soluble and petroleum ether-soluble extractive was preceded as directed for the determination of alcohol soluble extractive, using chloroform water, chloroform, petroleum ethersolvent instead of alcohol.

\section{Loss on Drying (Tambe, 2012)}

Loss on drying is the loss of mass expressed as percentage w/w. About 5-6g of drug powder was accurately weighed in a petri dish and kept in a hot-air oven maintained at $110^{\circ} \mathrm{C}$ for four hours. After cooling in desiccator, the loss in weight was recorded in each case. This procedure was repeated till the constant weight was obtained.

$$
\text { Loss on drying }(\%)=\frac{\text { Loss in weight }}{W} \times 100
$$

$\mathrm{W}=$ weight of the drugs in grams.

\section{Ash Values (Tambe, 2012)}

Total ash

A silica or platinum crucible was heated to redness for 30 min, allowed to cool in desiccators and weighed unless otherwise prescribed; $1 \mathrm{~g}$ of powdered drug to be examined in the crucible was distributed. It was dried at $100^{\circ} \mathrm{C}-105^{\circ} \mathrm{C}$ for $1 \mathrm{~h}$ and ignited to constant mass on Bunsen burner; the crucible was allowed to cool in desiccators after each ignition. Care was taken to ensure flames are not produced at any time during the procedure.

\section{Acid-insoluble ash}

The ash was boiled for 10 minutes with $25 \mathrm{ml}$ of dilute hydrochloric acid and the insoluble matter was collected on ash less filter paper in a crucible. It was then washed with hot water, ignited and weighed. The percentage of acid-insoluble ash was calculated with reference to the air-dried drug.

\section{Fluorescence Analysis (Thirumalai, 2013)}

Many crude drugs shows the fluorescence when the sample is exposed to the ultraviolet radiation. Evaluation of crude drugs based on fluorescence in daylight is not used as it is usually unreliable due to the weakness of the fluorescent effect (Umbelliferone test used for galbanum and asafoetida, however is an exception). Fluorescence lamps are fitted with suitable filters, which eliminate visible radiation of definite wavelength. Several crude drugs show characteristic fluorescence for their evaluation. 
Powder samples were subjected to fluorescence study with treatment of different reagents.

\section{Thin Layer Chromatography (Pradhan, 2013)}

The solvent mixture (petroleum ether: ethyl acetate; $2: 1$ ) was poured in to the TLC chamber and the chamber was closed with lid.The chamber was not disturbed for about 30 minutes so that the atmosphere in the jar becomes saturated with the solvent. A straight line was gently drawn across the plate using a pencil approximately $2 \mathrm{~cm}$ from the bottom.A capillary tube was used; a minute drop of extract was spotted on the line. The spot was then allowed to dry. Plate in the TLC chamber was placed as evenly as possible and leaned against the side (immersed the plate such that the line is above the solvent). Capillary action allowed drawing the solvent up the plate until it was approximately $1 \mathrm{~cm}$ from the end.Theplate was removed and immediately a pencil line is drawn across the solvent top.Under a hood, the plate was dried with the aid of a blow dryer.The plate was observed under UV light.The center of the spots was marked, the distance of the center of the spots from the origin was measured and the Retention Factor $\left(R_{f}\right)$ values were calculated.

\section{Extraction (Swaile, 2014)}

Soxhlet apparatus was used for extraction. It is a continuous hot extraction method. 3 to 4 boiling chips were placed into the solvent vessels, for example round bottom flask or cylindrical flask. The plant leaves powder was weighed into the extractor thimble.The extractor thimble was closed with filter paper. The Soxhlet extractor connection was placed on top of the flask.The thimble filled with $250 \mathrm{ml}$ of $95 \%$ ethanol was inserted into the Soxhlet extractor fitting into the thimble compartment.The condenser was connected on top of the Soxhlet extractor and the water flow was turned on.The heat was adjusted to monitor the regular flushing. The Soxhlet apparatus was switched on at suitable temperature and run for 2 to 3 days continuously.After 3 days of continuous extraction, the Soxhlet apparatus was switched off.The content in the round bottom flask was weighed.The extract was concentrated by using rotary evaporator.

\section{Phytochemical Screening}

Phytochemical screening was carried out by using standard methods as described in reference literature and reference text (Khandelwal, 2005).

Total Phenolic Content (Sharma, 2011)

Gallic acid stock solution (1000 microgram $/ \mathrm{mL}$ ) was prepared by dissolving 100mg gallic acid in $100 \mathrm{ml}$ ethanol.Various dilutions of standard gallic acid were prepared from this stock solution. Folin-Ciocalteau reagent was prepared by mixing Folin's reagent with phenol reagent (1:1) and diluted 1:1 in distilled water, before use. Calibration curve was plotted by mixing $1 \mathrm{ml}$ aliquots of $1,2,3,4,5$ and 6 microgram/millilitre of gallic acid solutions with $5 \mathrm{ml}$ of Folin-Ciocalteau reagent and $4 \mathrm{ml}$ of sodium carbonate solution. The absorbance was measured after
30 minutes at $765 \mathrm{~nm}$.Stock solution of extract was prepared by dissolving $10 \mathrm{mg}$ of extract in $100 \mathrm{ml}$ of $95 \%$ ethanol.The concentration of the ethanol extract stock solution is $100 \mu \mathrm{g} / \mathrm{ml}$. The stock solution of ethanol extract was diluted to $50 \mu \mathrm{g} / \mathrm{mL} .1 \mathrm{ml}$ of ethanol extract $(50 \mu \mathrm{g} / \mathrm{mL})$ was mixed separately, with the same reagent as what was done in construction of calibration curve, and after 1 hour, the absorbance was measured for determination of total phenolic compound in both the extract separately by using the formula:

\section{Total phenolic content, $C=A / B$}

C-expressed as mg GAE/g dry weight of extract

A-Equivalent concentration of gallic acid established from calibration curve (mg), B-Dry weight of extract

\section{RESULTS}

\section{Macroscopic Study}

The leaves were observed macroscopically for its external and organoleptic features. The leaves are alternate or irregular, ovate and finger-like shaped with an average of $30.21 \mathrm{~cm}$ in length $(20-40 \mathrm{~cm})$ and $24.25 \mathrm{~cm}$ in width $(17-36 \mathrm{~cm})$. These dicotyledon leaves have pinnate-type reticulate venation with deeply cut 7 to 8 lobes. The blades have glossy and rough texture with the midribs and the prominent veins are covered with reddishwhite hairs. The apexes of the leaves are acute, conical shaped crown with thick petioles having length of $4.2-4.8 \mathrm{~cm}$. The leaves have bitter taste with slight odour and they are dark green in colour on the dorsal side and yellowish green on the ventral side.

\section{Microscopic Study}

The results for microscopic study on TS of leaf are illustrated in figure 2 to 8 and powder microscopy in figure 9-14.

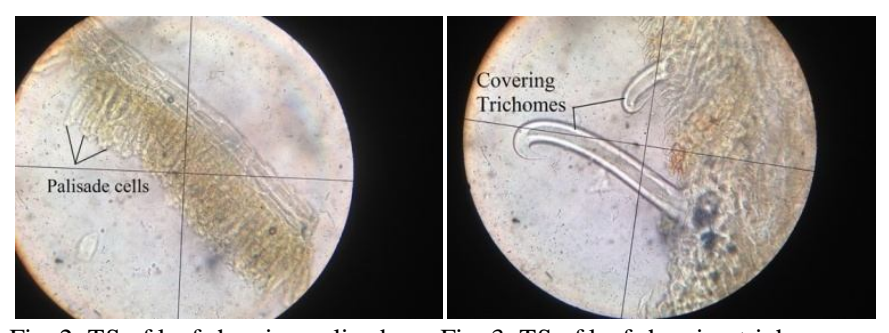

Fig. 2: TS of leaf showing palisade cell.

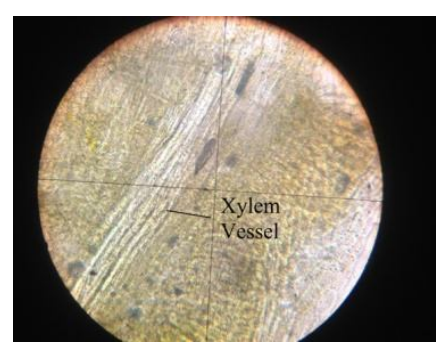

Fig. 4: TS of leaf showing xylem vessel.

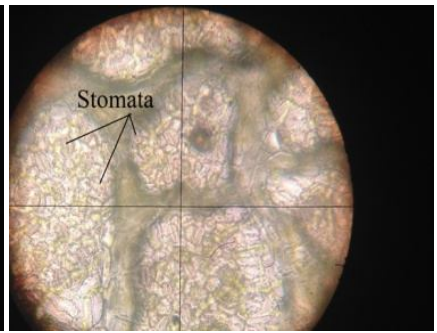

Fig. 5: TS of the leaf showing anomocytic stomata. 


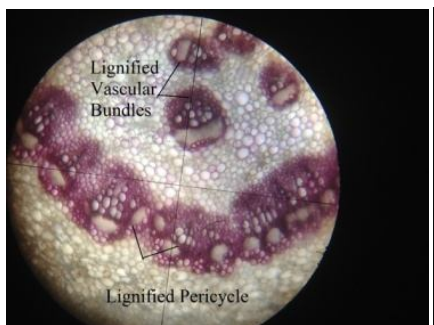

Fig 6: TS of the leaflet showing lignified vascular bundles and lignified pericycle after screening with phloroglucinol and

hydrochloric acid.

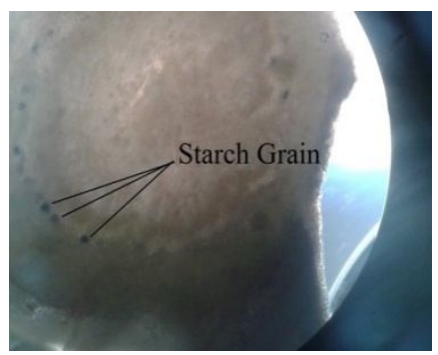

Fig. 8: TS of the leaf showing starch grain in blue colour with iodine sulphuric acid.

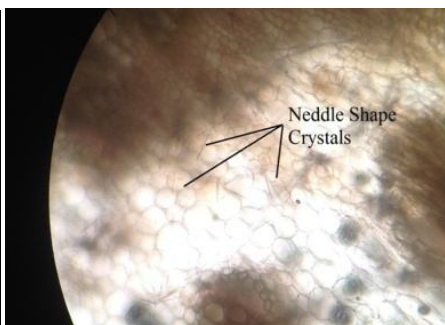

Fig. 7: TS of the leaf showing needle shape crystals with staining $60 \%$ sulphuric acid.

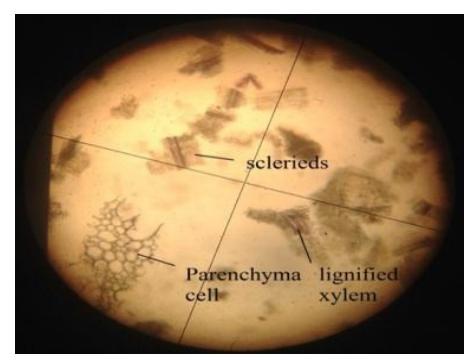

Fig. 9: Power microscopy on leaf showing the presence of sclerieds, parenchyma cell and lignified xylem after staining with phloroglucinol and hydrochloric acid.(1:1).

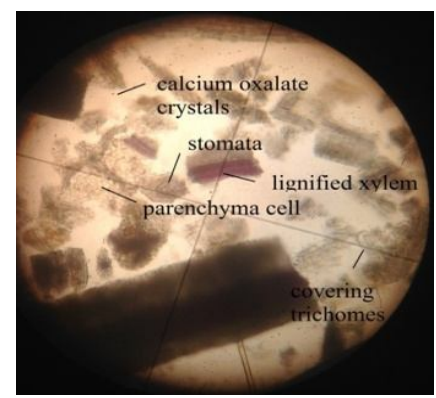

Fig 11: Powder microscopy showing the presence of calcium oxalate crystals, stomata, lignified xylem and covering trichomes after staining with phloroglucinol and hydrochloric acid (1:1).

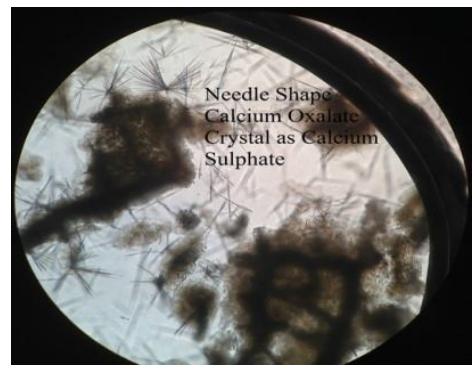

Fig. 13: Powder microscopy showing the present of needle shape calcium oxalate crystals as calcium sulphate after staining with concentrated sulphuric acid.

\section{Physiochemical Characterization}

Table 1: Extractive value

\begin{tabular}{ccc}
\hline S No & Parameters determined & Values in $(\%) \mathrm{w} / \mathrm{w}$ \\
\hline 1 & Alcohol-soluble extractive & 16 \\
2 & Water-soluble extractive & 21.32 \\
3 & Chloroform-soluble extractive & 8 \\
4 & Petroleum ether $\left(60^{\circ}-80^{\circ}\right)$-soluble & 9.33 \\
& extractive &
\end{tabular}

Table 2: Loss on drying

\begin{tabular}{ccc}
\hline S No & Parameters determined & Values in $(\%) \mathrm{w} / \mathrm{w}$ \\
\hline 1 & Loss on drying & 11.64 \\
\hline
\end{tabular}

Table 3: Total Ash value

\begin{tabular}{|c|c|c|c|c|}
\hline $\begin{array}{l}\text { Weight of } \\
\text { empty } \\
\text { crucible }(\mathrm{g})\end{array}$ & $\begin{array}{l}\text { Weight of } \\
\text { leaves } \\
\text { powder }(g)\end{array}$ & $\begin{array}{c}\text { Weight of } \\
\text { crucible }+ \\
\text { leaves powder }\end{array}$ & $\begin{array}{c}\text { Weight of } \\
\text { crucible + } \\
\text { ash }(g)\end{array}$ & $\begin{array}{c}\text { Total } \\
\text { Ash } \\
\text { value \% }\end{array}$ \\
\hline
\end{tabular}

\begin{tabular}{lllll}
23.16 & 2 & 25.16 & 23.34 & 9 \\
\hline
\end{tabular}

Table 4: Acid insoluble ash

\begin{tabular}{lllll}
\hline $\begin{array}{l}\text { Weight of } \\
\text { empty } \\
\text { crucible }(\mathrm{g})\end{array}$ & $\begin{array}{l}\text { Weight } \\
\text { of ash } \\
(\mathrm{g})\end{array}$ & $\begin{array}{l}\text { Weight of } \\
\text { crucible }+ \\
\text { ash }(\mathrm{g})\end{array}$ & $\begin{array}{l}\text { Weight of crucible } \\
+ \text { ash after treated } \\
\text { with dilute HCL } \\
(\mathrm{g})\end{array}$ & $\begin{array}{l}\text { Acid- } \\
\text { insoluble } \\
\text { Ash value } \\
\%\end{array}$ \\
\hline 23.16 & 0.18 & 23.34 & 23.17 & 0.5 \\
\hline
\end{tabular}

\section{Fluorescence Analysis}

Table 5: The fluorescence characteristics of leaf powder under UV after treating with different chemical reagents.

\begin{tabular}{|c|c|c|c|c|}
\hline \multirow[b]{2}{*}{ SI No } & \multirow[b]{2}{*}{$\begin{array}{l}\text { Particulars of } \\
\text { treatment }\end{array}$} & \multirow[b]{2}{*}{$\begin{array}{c}\text { Under ordinary } \\
\text { light }\end{array}$} & \multicolumn{2}{|c|}{ Under UV light } \\
\hline & & & $\begin{array}{c}\text { Short } \\
\text { Wavelength } \\
(254 \mathrm{~nm})\end{array}$ & $\begin{array}{c}\text { Long } \\
\text { Wavelength } \\
(366 \mathrm{~nm})\end{array}$ \\
\hline 01 & Leaf Powder & Green & No florescence & No florescence \\
\hline 02 & Powder $+50 \% \mathrm{H}_{2} \mathrm{SO}_{4}$ & Greenish yellow & Greenish black & Greenish black \\
\hline 03 & Powder + 1N NaOH & Golden yellow & Brown & Orange \\
\hline 04 & Powder + Dist. Water & Light green & Greenish black & Greenish black \\
\hline 05 & Powder + Ammonia & Dark orange & Dark green & Yellowish brown \\
\hline 06 & Powder + $\mathrm{MeOH}$ & Dark green & Dark greenish & Dark green \\
\hline 07 & Powder + Acetic acid & Yellowish green & No florescence & No florescence \\
\hline 08 & Powder + 5\% KOH & Orange & Greenish black & Brown \\
\hline 09 & Powder $+5 \% \mathrm{FeCl}_{3}$ & Dark green & Light green & Light green \\
\hline 10 & Powder + 1N HCl & Yellowish green & Light green & Green \\
\hline 11 & Powder $+50 \% \mathrm{HNO}_{3}$ & Golden yellow & Light yellow & Light yellow \\
\hline 12 & Powder $+5 \%$ Iodine sol. & Dark brown & Dark green & Dark green \\
\hline
\end{tabular}




\section{Thin Layer Chromatography}

Total 4 spots with $\mathrm{R}_{\mathrm{f}} 0.9,0.66,0.48,0.34$ wereobserved.

\section{Phytochemical analysis}

Phytochemical analysis revealed the presence of carbohydrate, steroids, tannins, Anthraquinone Glycoside and Flavonoids.

\section{TOTAL PHENOLIC CONTENT}

The graph of total phenolic contentis illustrated in Figure 15. The phenolic content in the ethanolic extract was found to be 26.22 GAE/g.

\section{Total phenolic content, $C=A / B$}

C-expressed as mg GAE/g dry weight of extract, A-Equivalent concentration of gallic acid established from calibration curve (mg), B-Dry weight of extract.

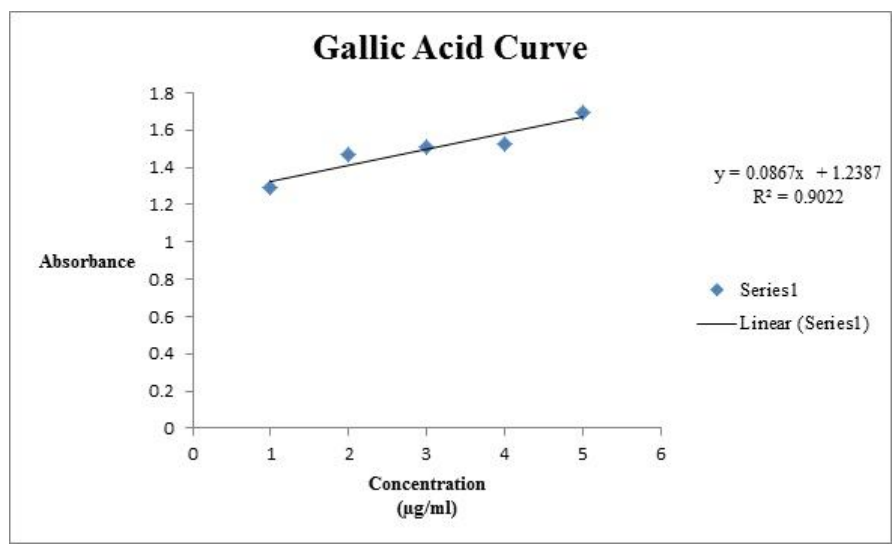

Fig 15: Total phenolic content of Artocarpusaltilis (Parkinson) Fosberg leaves.

\section{DISCUSSION}

Inmacroscopic study,the observedmorphological features of the leaf of Artocarpusaltilis were in agreement with reported literature.In microscopic study, the pictures of transverse section of Artocarpus altilis leaves showed the presence of palisade cell which is the diagnostic feature of the leaves. Results of the microscopy suggested that xylem vessels were pink in colour after treatment with phloroglucinol; this is due to the presence of the lignin in xylem vessel. On treatment with $60 \%$ of sulphuric acid, the calcium oxalate crystals change their shape and turn needle shape due to conversion as calcium sulphate. On treatment with iodine, the transverse section show the presence of the starch grains with blue colour, The microscopic study also showed the presence of anomocytic stomata which is commonly found in Artocarpus genus.

Distilled water extract showed the has highest extractive value which was found to be $21.32 \%$ compared to alcohol soluble, chloroform soluble and petroleum ether soluble extractive value. This may be due to presence of high amount of polar compounds in the leaves of selected plant. The loss of drying value was found to be $11.6 \% \mathrm{w} / \mathrm{w}$. Initial weight of the powder before drying was high due to presence of moisture content in the powder. When the powder was heated in hot air oven, the water content in the powder gets evaporated so the final weigh of the powder after drying decreased. Total ash and acid-insoluble ash contents are important indices to illustrate the quality as well as purity of the crude drug and also indicate the presence of inorganic material in crude drug. Total ash content alone is not sufficient to reflect the quality of leaves, since the plant materials often contain calcium oxalate in particular. Thus, acid-insoluble ash content is another parameter to illustrate the quality of drugs. The total ash value was found to be $9 \%$ and the acid-insoluble value was $0.5 \%$. Total ash value showed higher percentage than acid-insoluble value.

In fluorescence analysis,powder fluorescence characteristics of leaf under UV light after treating with different chemical reagents and proximate analysis of the powdered drug were listed in Table 5. The fluorescence colour is specific for each class of chemical compounds. Leaves powder shows fluorescence because the powder can absorb the reagent and the compound in the powder that has fluorescence property will fluoresce. This will help to identify the class of phytochemical compound present in plant.

Thin Layer Chromatography (TLC) is a solid-liquid technique in which the two phases are a solid, stationary phase and a liquid, mobile phase. The $\mathrm{R}_{\mathrm{f}}$ of any given molecule will vary depending on the mobile and stationary phases used. $30 \mathrm{ml}$ of petroleum ether and $15 \mathrm{ml}$ of acetyl acetate $(2: 1)$ as the mobile phase and silica gel plate as the stationary phase were used in this study. The standard $R_{f}$ value of gallic acid as per British Pharmacopeia is $0.35 \pm 0.01$. Four spots were clearly visible on the TLC plate when subjected under ultraviolet ray $(254 \mathrm{~nm})$. The $R_{f}$ value of spot number 4 i.e., 0.34 coincides with the standard $R_{f}$ value of $0.35 \pm 0.01$, confirming the presence of gallic acid in the ethanolic extract of the Artocarpus altilis leaves.

The results of qualitative phytochemical investigations of Artocarpus altilishave revealed the presence of flavonoids, steroid, and glycosides. Phytochemical findings are in agreement with the reported literature and were confirmed by qualitative chemical tests.

The estimation of total phenolic content was based on the absorbance of sample and Folin-Ciocalteau reagent mixture at 765 $\mathrm{nm}$. Gallic acid was used as a standard compound and the total phenols were expressed as $\mu \mathrm{g} / \mathrm{mLgallic}$ acid equivalent using the standard curve equation: $\mathrm{y}=0.0079 \mathrm{x}+1.476, \mathrm{R}^{2}=0.9949$, where $\mathrm{y}$ is the absorbance at $765 \mathrm{~nm}$ and $\mathrm{x}$ is the total phenolic content expressed in $\mu \mathrm{g} / \mathrm{gm}$. The phenolic content in the ethanolic extract was found to be $26.22 \mathrm{GAE} / \mathrm{g}$.

\section{CONCLUSION}

Artocarpus altilis plant leaves were selected for this study.The method used for extraction of Artocarpus altilis was Soxhlet extraction method. All the standardization parameters for the leaves of selected plant were done according to the pharmacopoeia standards and results of these parameters were found within limits. Based on the studies conducted, it was confirmed that the plant contains flavonoid, steroid and glycosides.Phenolic compound were also present in the alcoholic 
extract. From this study, it can be concluded that the Artocarpus altilis leaves extracts contains modest amount of phenolic compounds in the leaves of the plant.

In future,further investigations are required to check its antioxidant activity as present study suggests the presence of phenolic content.

\section{ACKNOWLEDGMENT}

Authors express their heartfelt thanks to Prof. Dr. S. A. Dhanaraj, Professor and DVC (Research \& innovation), Faculty of Pharmacy, AIMST University for his constant encouragement and support during this research work. Authors express their deepest gratitude to Dr. K. Santhi, the research coordinator, Faculty of Pharmacy, AIMST University for valuable suggestions during the time of this research work.

\section{REFERENCES}

A.M.P. Jones, D. Ragone, N.G. Tavana, D.W. Bernotas, and S.J. Murch. Beyond the Bounty: Breadfruit (Artocarpus altilis) for food security and novel foods in the 21st Century. Ethnobotany journal.2011; 9: 131-132.

Akanbi T.O., Nazamid, S. and Adebowale, A.A. Functional and pasting properties of a tropical breadfruit (Artocarpus altilis) starch from Ile-Ife, Osun State, Nigeria. International Food Research Journal. 2009; 1(6): 151.

Amarasinghe N.R., Jayasinghe L., Noriyuki Hara, Yoshinori Fujimoto. Chemical constituents of the fruits of Artocarpus altilis.Science Direct Biochemical Systematics and Ecology. 2007; 36 (2008): 323-325. [Online] Available from: /http://www.sciencedirect.com/science/article/pii/S030519780700201 3[Accessed 1st February 2014].

Arya V., Thakur R. Organoleptic and Microscopic Analysis of Gentinaregeliana.Journal of Pharmacognosy and Phytochemistry. 2012; 1(2): 32-35.

Beverly Swaile. Soxhlet extraction of fat from french fries. [Online] Available from: http://www.slideshare.net/princeelackad/Soxhlet-extraction [Accessed 21th April 2014].

Carolyn Glatz. An Introduction to Herbalism.Healthy Life Journal.[Online] Available from: http://healthylifejournal.org/articles/an-introduction-to-herbalism/ [Accessed 22th April 2014].

ChinmayPradhan. Assessment of the antibacterial potential of breadfruit leaf extracts against pathogenic bacteria.International Journal of Pharmacy. 2013; 3(2):374-379.

Handa S.S., Khanuja S.P.S., Gennaro Longo et al. Extraction technologies for medicinal and aromatic plants. International centre for science and high technology. [Online] 2008. Available from: http://agritech.tnau.ac.in/horticulture/extraction_techniques\%20_medi cinal_plants.pdf [Accessed 3rd February 2014].

History of Use of Traditional Herbal Medicines.IARC Monographs [Online] Available from: http://monographs.iarc.fr/ENG/Monographs/vol82/mono82-6A.pdf [Accessed 22th April 2014].
Hot Maceration Extraction Procedure. [Online] Available from:https://workspace.imperial.ac.uk/library/Public/Vancouver_refer encing.pdf [Accessed 21th April 2014]

Jagtap U.B., Bapat VA. Artocarpus: A review of its traditional uses, phytochemistry and pharmacology. Journal of Ethnopharmacology. [Online] 2010; 12(9): 143-144. Available from: www.elsevier.com/locate/jethpharm [Accessed 21th January 2014].

Jhanwar Bharat. Determination of Quality Standards for Herbal Formulation: ChaturjatChurna. Journal of Pharmacognosy and Phytochemistry . 2013; 2(1):103-104.

Khandelwal KR. Preliminary Phytochemical Screening.Practical Pharmacognosy.2005; 146-157. [Online] Available from: http://www.allbookez.com/kokate-practicalpharmacognosy/ [Accessed 21th January 2014].

Lassens Natural Foods and Vitamins.Breadfruit (Artocarpus altilis). [Online] Available from: www.naturalstandard.com [Accessed 21th January 2014].

Morton JF. Fruits of warm climates.United State: Julia F. Morton Publishing; 1987.

Osmene K.P, Elujoba A.A, llori M.O.An Overview of Herbal Medicine Research and Development in Nigeria.Research Journal Of Medical Sciences. 2011; 5(4): 228-232.

Salahuddin, Fuloria S., Pahwa S., Kumari S. and Gupta S.K. Studies on Morpho-microanatomical Evaluation of the Leaves of Tridaxprocumbens Linn (Astteraceae). Journal of Scientific Research.2010; 2(3):613-619.

Sharma G.N. Phytochemical screening and estimation of total phenolic content in Aeglemarmelos seeds.International Journal of Pharmaceutical and Clinical Research. 2011; 3(2): 27-29.

Somashekhar M, Naira Nayeem, BasavrajSonnad. A Review on Family Moraceae (Mulberry) With a Focus on Artocarpus Species.World Journal Of Pharmacy And Pharmaceutical Sciences. 2013; 2(5): 2614-2621.

Sushmita and Naira Nayeem. Artocarpus altilis: Over View of a Plant which is referred to as Bread Fruit. International Journal of Pharmaceutical Sciences Letters. 2013; 3(5): 1-3.

Tambe S.S. Determination of ash values of some medicinal plant of Marathwada region in Maharashtra. International Journal of Pharmaceutical Research and Bio-science.2012; 1(3): 337-346.

Thin Layer Chromatography procedure. [Online] Available from: http://amrita. vlab.co.in/?sub=3\&brch=63\&sim=154\&cnt=2 [Accessed 21th April 2014].

Thirumalai D. Evaluation of physiochemical, pharmacognostical and phytochemical parameters of PremnaHerbacea.Asian Journal of Pharmaceutical and Clinical Research. 2013;6(1): 173-181.

Timothy J. Motley. Breadfruit origins, diversity and human facilitated distribution. [Online] Available from:http://herbarium.millersville.edu/325/Zerega-2005.pdf [Accessed 21th January 2014].

\section{How to cite this article:}

Mukesh S. Sikarwar, Boey Jia Hui, Kumutha Subramaniam, Bavani Devi Valeisamy,Ling KarYean, Kaveti Balaji.Pharmacognostical, Phytochemical and Total Phenolic Content of Artocarpus Altilis (Parkinson) Fosberg Leaves. J App Pharm Sci, 2015; 5 (05): 094100. 